ИЗВЕСТИЯ АКАДЕМИИ НАУК ЭСТОНСКОИ ССР. ТОМ 32 ХИМИЯ. 1983, № 1

\title{
БИТУМИНОЛОГИЧЕСКАЯ ХАРАКТЕРИСТИКА БОЛГАРСКОГО БОГХЕДА МЕСТОРОЖДЕНИЯ БОРОВ ДОЛ
}

Сланцевое месторождение Боров Дол НР Болгарии - одно из перспективных для промышленной разработки: толщина слоя горючего сланца составляет 50-90 м. Этот сланец весьма беден органическим веществом. Между пачек сланца находится генетически с ним связанный узкий слой (40 см) богхеда [']. Богхедом называется уголь класса собственных сапропелитов, характерный признак которого - большое количество водорода. Богхед содержит $48,0 \%$ органического вещества $(\mathrm{OB})$, элементный состав его, вес.\%: $\mathrm{C}-66,5 ; \mathrm{H}-8,1 ; \mathrm{N}-2,4$; $\mathrm{S}-2,7 ; \mathrm{O}-20,4$ и атомное отношение $\mathrm{H} / \mathrm{C}-1,46$. По элементному составу ОВ богхеда близко к керогену горючего сланца.

Для выделения битумоида А богхед был подвергнут исчерпывающему экстрагированию хлороформом, а потом, после обработки $10 \%$-ной соляной кислотой, смесью бензола и метанола $(3: 1)$ выделили битумоид С. Данные, характеризующие выделенные битумоиды, представлены в табл. 1. По данным $\left[{ }^{2,3}\right]$, хлороформом извлекаются в основном нейтральные соединения и свободные кислоты, которые имеют низкий молекулярный вес. Қислоты с более высоким молекулярным весом экстрагируются полярным растворителем вместе с кислотами, освободившимися при солянокислотной обработке.

Обычно парафины концентрируются в битумоиде А. Установили, что индивидуальный состав кислот обоих битумоидов близок. Далее, для

Таблица 1

Таблица 2

Состав битумоидов А и С болгарского богхеда месторождения Боров Дол, вес. $\%$

\begin{tabular}{l|r|r|r}
\hline Показатели & A & C & A+C \\
\hline Выход на ОВ & 2,9 & 2,5 & 5,4 \\
Элементный сос- & & & \\
тав: & 80,0 & 74,5 & 77,0 \\
$\mathrm{C}$ & 11,7 & 9,1 & 10,5 \\
$\mathrm{H}$ & 0 & 1,5 & 0,7 \\
$\mathrm{~N}$ & 1,0 & 2,0 & 1,4 \\
$\mathrm{~S}$ & 7,3 & 12,9 & 9,4 \\
O & & & \\
Групповой сос- & & \\
тав: & & \\
нейтральный & \\
бнтумоид & - & - & 50,4 \\
карбоновые & & & \\
кислоты & - & - & 32,7 \\
нераствори- \\
мые кис- \\
лоты
\end{tabular}

Групповой состав битумоидов $\mathrm{A}+\mathrm{C}$, вес. $\%$

\begin{tabular}{l|c}
\hline Название групп соединений & $\mathrm{A}+\mathrm{C}$ \\
\hline Парафины & 9,0
\end{tabular}

Нейтральные гетероатомные соединения:

малополярные сильнополярные

Кислоты: жирные поликарбоновые

Потери хроматографирования 


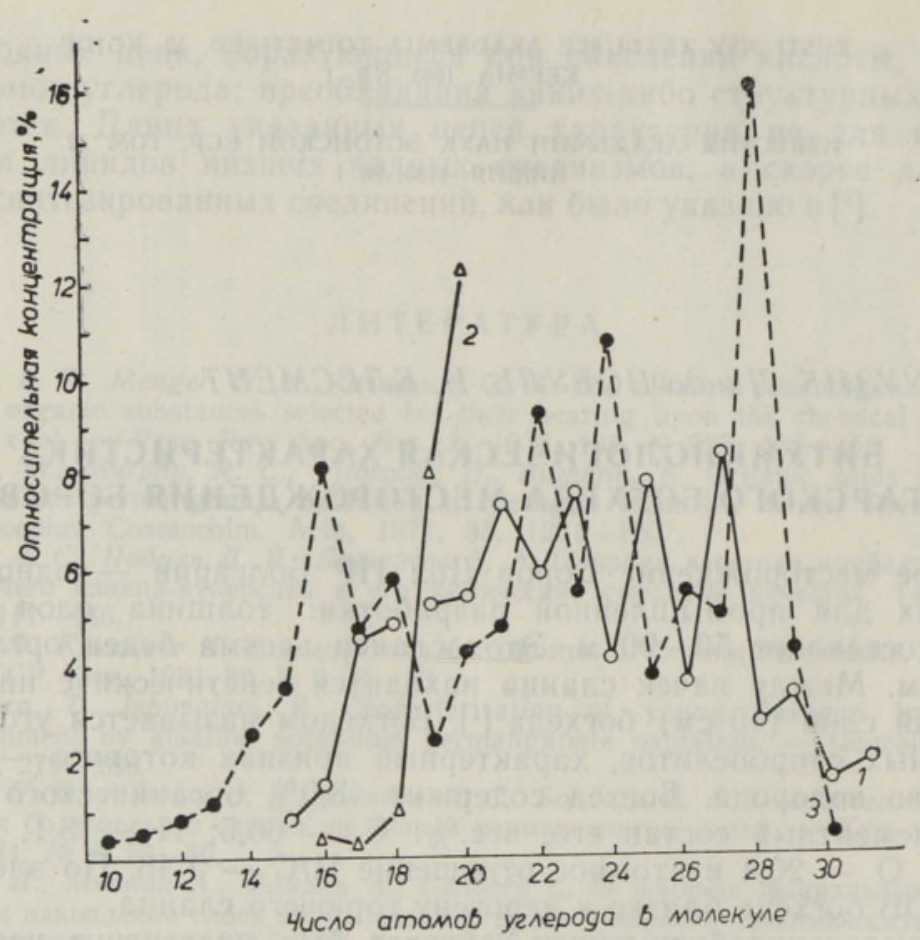

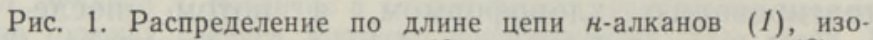
преноидных углеводородов (2) и жирных кислот (3) в битумоидах болгарского богхеда.

уменьшения объема аналитических работ исследовали суммарный битумоид $(\mathrm{A}+\mathrm{C})$, составленный из обоих компонентов. Омылением спиртовой щелочью суммарный битумоид разделили на нейтральные и кислые составляющие, в последних были как связанные, так и свободные кислоты, содержащиеся в исходном богхеде. Часть кислот оказалась нерастворимой в эфире (табл. 1). Половину битумоида составляют нейтральные соединения.

Кислые и нейтральные составляющие разделяли методом препаративной тонкослойной хроматографии $\left[{ }^{4}\right]$ на более узкие группы (табл. 2). Парафинов и жирных кислот мало (соответственно 9 и 16\%), это часто наблюдается в битумоидах, выделенных из несозревших осадочных отложений. Основными компонентами являются нейтральные гетероатомные соединения и поликарбоновые кислоты, присутствующие в равных количествах. Гетероатомные соединения составляют две трети битумоида.

Парафины и жирные кислоты анализировали на хроматографе «Хром-4». Колонки ( $\varnothing 3$ мм) имели следующую характеристику: $4 \%$ E 301 на хроматоне N AW HMDS $(0,125-0,160$ мм), длина 2,5 и 4 м; 2,6\% XE 60 на хроматоне N AW HMDS (0,20-0,25 мм), длина 3,7 м; $5 \%$ полиэтиленгликоля на инертоне $\mathrm{AW}(0,20-0,25 \mathrm{mм})$, длина 3,5 м. Состав парафинов и кислот представлен на рис. 1. Присутствуют $H$-парафины $\mathrm{C}_{14}-\mathrm{C}_{33}$, но преобладают парафины с длинной углеродной цепью $\mathrm{C}_{21}-\mathrm{C}_{27}$, имеющие преимущественно нечетное число углеродных атомов. Это - типичные восковые парафины, которые происходят из наземных растений [5]. Ациклические изопреновые углеводороды представлены соединениями $\mathrm{C}_{16}-\mathrm{C}_{20}$, при этом довольно много $i \mathrm{C}_{19}$ и $i \mathrm{C}_{20}$ (пристана и фитана). Отношение $i \mathrm{C}_{20}: i \mathrm{C}_{19}$ составляет 1,5 , что указывает на восстановительные условия фоссилизации хлорофилл- 


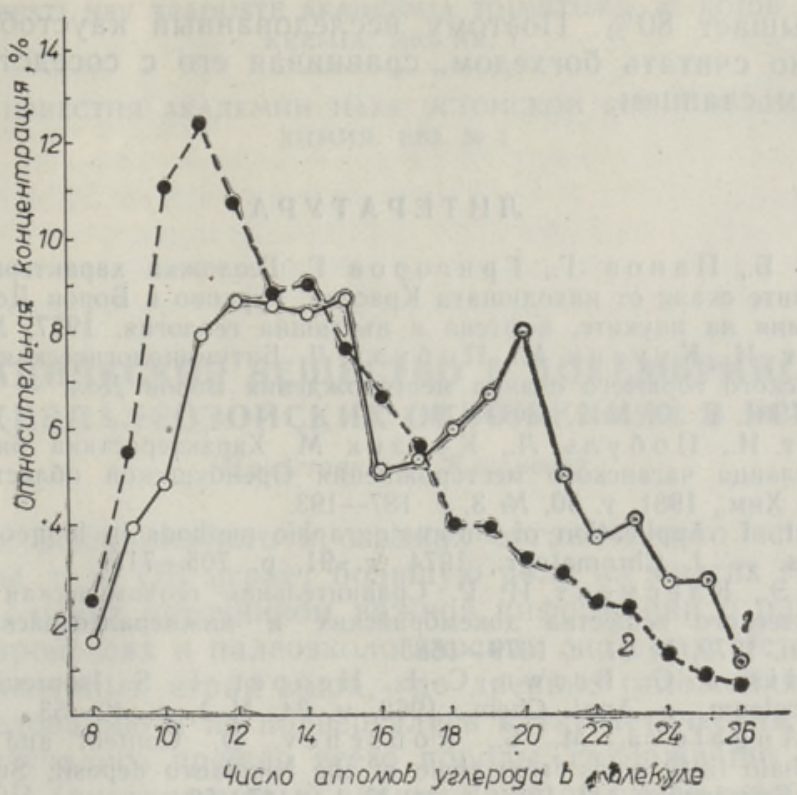

Рис. 2. Распределение по длине цепи $\boldsymbol{H}$-алканов (1) и н-алкенов (2) пиролизата поликарбоновых кислот битумоида.

содержащих наземных растений [6]. Состав парафинов такой же, как у парафинов выше- и нижележащих пачек горючих сланцев $\left[{ }^{2}\right]$.

В битумоиде присутствуют монокарбоновые (жирные) кислоты $\mathrm{C}_{10}-\mathrm{C}_{30}$, но нет дикарбоновых. Высокую концентрацию имеют четные кислоты $\mathrm{C}_{22}-\mathrm{C}_{28}$. Концентрация последнего гомолога наивысшая, как и в битумоиде болгарского сланца месторождения Николаево [7]. В битумоиде имеются также обычные, невоскового происхождения кислоты $\mathrm{C}_{16}-\mathrm{C}_{18}$. Следует отметить, что в окружающем сланце доминирует кислота $\mathrm{C}_{22}$. Между парафинами и кислотами битумоида наблюдается довольно хорошая корреляция; это - редкое явление, в большинстве случаев парафины и кислоты имеют различный состав. Корреляция указывает на то, что парафины могли образоваться путем декарбоксилирования кислот. Присутствуют также изопреновые кислоты $\mathrm{C}_{19}-\mathrm{C}_{22}$.

Битумоид содержит выше $30 \%$ полифункциональных кислот, которые имеют относительно высокий молекулярный вес и газохроматографически не разделяются. Для получения ориентировочных данных о длине их алифатических цепей проводили пиролиз поликарбоновых кислот в стеклянной трубке. Состав парафинов и олефинов пиролиза представлен на рис. 2. Видно, что алифатические цепи карбоновых кислот короче цепей жирных кислот и парафинов. Поликарбоновые кислоты битумоида сланцев того же месторождения имеют алифатические цепи, содержащие более 20 атомов углерода.

Состав битумоида богхеда месторождения Боров Дол дает возможность предположить, что исходным веществом при его образовании служили также наземные растения и процессы фоссилизации проходили в восстановительной среде. По составу битумоида органическое вещество богхеда мало отличается от окружающего его горючего сланца. Основное различие - разные концентрации ОВ в сланцах $(10-19 \%)$ и в богхеде $(48 \%)$. Следует отметить, что богхеды обычно содержат больше ОВ, в иркутских и оленекском бассейнах его содер- 
жание превышает $80 \%$. Поэтому исследованный каустобиолит можно лишь условно считать богхедом, сравнивая его с соседствующим бедным горючим сланцем.

\section{ЛИ Т Е Р А Т У Р А}

1. Каменов Б., Панов Г., Григоров Г. Геоложка характеристика на битуминозните скали от находищата Красава, Гурково и Боров Дол. - Българска Академия на науките, нефтена и въглищна геология, 1977, № 7, с. 5-15.

2. Клесмент И., Куузик М., Побуль Л. Битуминологическая характеристика болгарского горючего сланца месторождения Боров Дол. - Изв. АН ЭССР. Хим., 1981 , т. 30 , № 2, с. $69-74$.

3. Клесмент И., Побуль Л., Куузик М. Характ̦еристика битумоидов горючего сланца чаганского месторождения Оренбургской области. - Изв. АН ЭССР. Хим., 1981, т. 30, № 3, с. 187-193.

4. Klesment, I. Application of chromatographic methods in biogeochemical investigations. - J. Chromatogr., 1974, v. 91, p. 705-715.

5. У ров К. Э., Клесмент И. Р. Сравнительная геохимическая характеристика органического вещества докембрийских и ннжнепалеозойских сланцев. Геохим., 1979, № 11, с. 1679-1685.

6. B endoratis, J. G., B rown, C. L., Hepper, L. S. Isoprenoid hydrocarbons in petroleum. - Anal. Chem., 1962, v. 34, N 1, p. 49-53.

7. Dodova-Angelova, M. S., Rouschev, D. Content and composition of long-chain fatty acids from shale of the Nikolaevo deposit, South-Bulgaria. Докл. Болгарской АН, 1981, т. 34, № 1, с. 47-50.

Институт химии

Академии наук Эстонской ССР
Поступила в редакцию 12/III 1982

Maret KUUSIK, Linda POBUL, I. KLESMENT

\section{BULGAARIA BOROV DOLI LEIUKOHA BOGHEDI BITUMINOLOOGILINE ISELOOMUSTUS}

Vaadeldud boghed sisaldab $48 \%$ orgaanilist ainet, milles on $5,4 \%$ bitumoide. Parafiinidel $(9 \%)$ ja rasvhapetel $(16 \%)$ on pikad süsinikuahelad; ülekaalus on paarituarvulise ahelaga parafiinid ja paarisarvulise ahelaga happed, mis pärinevad maismaataimedest. Bitumoid koosneb põhiliselt suure molekulmassiga heteroühenditest. Boghed ja teda ümbritsev põlevkivi on geneetiliselt seotud.

Maret KUUSIK, Linda POBUL, I. KLESMENT

\section{CHARACTERIZATION OF BOROV DOL BOGHEAD COAL BITUMEN}

The Borov Dol boghead coal (Bulgaria) contains $48 \%$ of organic matter with $5.4 \%$ of bitumen content. Paraffins $(9 \%)$ and fatty acids $(16 \%)$ have long carbon chains, odd paraffins and even acids being formed mainly from terrestrial plants.

The bitumen consists mainly of heterocompounds with a high molecular weight.

The coal and the surrounding oil shale are genetically related. 